In 1891, at the International Congress of Hygiene, Copeman described his technique for the bacteriological purification and preservation of vaccine lymph by the admixture of glycerin. This, as he observed, was no new device, but he was the first to demonstrate the selective action of glycerin in eliminating extraneous organisms from the lymph without affecting the specific virus. Later, with F. R. Blaxall, he showed that glycerin is superior to soft paraffin and lanolin in inhibiting the growth of these micro-organisms.

With Dr. Gustav Mann, Copeman collaborated in a study of the histology of vaccinia and investigated other aspects of variola and vaccinia.

As a result of Copeman's work, 'arm-to-arm' vaccination with its attendant risks was abolished, and vaccination was made a much safer and simpler operation. His work was generally adopted by the Royal Commission on Vaccination.

Copeman's discoveries are chiefly recorded in the Proceedings of the Royal Society, the annual reports of the Medical Officer of the Local Government Board, and in his Milroy Lectures under the title of "The Natural History of Vaccinia" (1898). He was elected a fellow of the Royal Society in 1903. He received many distinctions; for example, the Buchanan Gold Medal of the Royal Society in 1902 ; the Cameron Prize of the University of Edinburgh in 1899, and the Fothergill Gold Medal of the Medical Society of London in the same year ; and the Jenner Medal of the Royal Society of Medicine (1925) and the Gold Medal of the International Faculty of Sciences (1938).

Although Copeman was employed in numerous administrative inquiries for the Central Health Department both at home and abroad, acted as Government delegate and served on many departmental committees, his real interest lay in scientific research, and his alert mind, fertile in new ideas, was directed to various subjects of investigation. During his later years at the Ministry of Health, he paid special attention to the problem of cancer, and his report with Prof. Major Greenwood on "Diet and Cancer with special reference to the Incidence of Cancer upon Members of certain Religious Orders" opened a new field of inquiry. In 1928, at the International Cancer Congress held in London, he read a paper on irradiated fluorescein in the treatment of cancer. He was a member of the Ministry of Health's Departmental Committee on Cancer, where his advice and ripe experience proved of much value. He was also a pioneer in immunization against diphtheria in Great Britain. During the First World War, Copeman was in charge of the Hygiene Department of the Royal Army Medical College, and helped with others to improve preventive medicine in the field. Endowed with untiring energy and enthusiasm, he took an active part in many medical societies and organisations. $\mathrm{He}$ was a keen naturalist and biologist and, as a member of the council of the Zoological Society, did much to develop its work on scientific lines.

On his official retirement in 1925, Copeman interested himself in local government as a member of the London County Council and chairman of the Public Health Committee of the Hampstead Borough Council. He died on April 11, at the age of eighty-five. To the end he kept himself informed of modern progress in medical research. He had a distinguished appearance and a generous and kindly disposition. A man of wide culture, he was a delightful companion. Copeman did much to maintain the high standard of English State medicine.

A. S. MacNaLty

\section{Prof. W. L. Valentine}

Willard Lee Valentine, editor of Science since January 1, 1946, died at his home in Alexandria, Virginia, on April 5. Sudden heart failure ended his career at the age of forty-two. He is survived by his wife, Norma Lawrence Valentine, and two children, Richard and Virginia.

Dr. Valentine was born in Chillicothe, Ohio, on December 2, 1904. He received the A.B. degree at Ohio Wesleyan University in 1925 and the Ph.D. at Ohio State University in 1929. During his years of graduate study, he served as assistant in mathematics and psychology, and later as instructor at Ohio Wesleyan and as instructor in psychology at Ohio State Universities.

Upon receiving his Ph.D. degree, he became a member of the Psychology Department at Ohio State University, first as assistant professor and later as associate professor. His duties there during 1929-40 were principally the direction and coordination of the work of the numerous instructors who gave the introductory courses in psychology. His strong interest in improving the teaching given to elementary psychology students led him during these years to write a manual of psychological experiments and to edit several collections of readings in psychology. His work during these years gave many students more interesting, and more experimental, courses than were often taught formerly.

In 1940 Dr. Valentine moved to Northwestern University in Evanston, Illinois, where he served as professor of psychology and chairman of the department until 1945.

From 1937 until his death he was treasurer of the American Psychological Association. During 1938-45 he served as business manager of the Association's publications. His careful supervision strengthened the journals financially, increased their number, and made them available to a steadily increasing group of subscribers.

His editorial skill and his experience with psychological publications led to his appointment as editor of Science when that journal came under the editorial direction of the American Association for the Advancement of Science. From the autumn of 1945 , when he began planning his first issue, until his death, he devoted himself to making Science a news magazine of interest to workers in all fields of science. The format was improved and the scope of articles broadened. Material of general interest to all men of science, such as discussions of the Science Foundation bills being debated by Congress, became, under his editorship, a prominent feature of the journal.

His untimely death has ended a life of service to psychologists and scientific workers in other fields, just as Dr. Valentine was reaching his prime.

\section{DAEL L. WOLFLE}

\section{Mr. C. W. Hobley, C.M.G.}

Charles Wirliam Hobley died at his residence at Oxted, Surrey, on March 31 in his eightieth year. For the past six years or so his health had been frail and his activity was considerably reduced. He will be best remembered for his pioneer work for the prevention of the threatened extermination of some of the more graceful mammals. He was also an authority on the life, both human and wild, of East Africa.

Born in 1867, the son of William Hobley, of Chilvers Coton, near Nuneaton, Warwickshire, Hobley was 
educated at Mason College (now part of the University of Birmingham), specializing in geology. In 1890 he was appointed to a post as geologist in the service of the Imperial British East Africa Company, and as the result spent the whole of his official life in East Africa. When the region was taken over by the Government and became the East Africa Protectorate, Hobley was transferred to the administrative side, being appointed a sub-commissioner in 1894, and as time went on was allotted posts of ever greater responsibility. He was acting deputy commissioner from 1903 until 1904 and again from 1906 until 1907, acting commissioner in 1904, and acting senior commissioner in 1907. In 1912 he was placed in charge of the Seyidieh Province, and during 1912-20 he was an official member of the Legislative Council of the East Africa Protectorate as well as Commissioner of Mines. Upon the outbreak of the First World War, Hobley was appointed chief political officer to the British Expeditionary Force in East Africa, his services receiving mention in dispatches. $\mathrm{He}$ retired from the Colonial Service in 1921. $\mathrm{He}$ had been awarded the C.M.G. in 1904. An important valley on the east side of Mount Kenya was named after him.

All his life Hobley retained a keen interest in Nature, especially in East Africa, where he varied his official duties by making several extensive and important collections for the British Museum. $\mathrm{He}$ belonged to the Royal Anthropological Institute, the Royal Geographical Society, and the Geological Society, and served on the councils of the first two in 1931 and of the third in 1930; he was also a corresponding fellow of the Zoological Society. In 1930 he became a member of the Advisory Board of the Geological Survey of Great Britain. His greatest services were, however, rendered to the movement to provide protection for animal species which otherwise, owing to ruthless commercial exploitation, would seriously diminish in numbers. In 1923 he was appointed secretary of the Society for the Preservation of the Fauna of the Empire, and held the post for thirteen years, until in 1936 health reasons compelled him to take life more easily. In 1931 he represented the Society at the Second International Conference for the Protection of Nature held at Paris. It may be recalled that as an immediate consequence of this Congress a conference of the African Powers was held in London in 1933, which produced the Convention for the Protection of the Fauna and Flora of Africa now in force. His services to the Society were recognized by his election as vice-president.

Hobley married the daughter of the late Thomas Turner, of Sutton Coldfield, in 1905; she died in 1940. The son and daughter of the marriage survive.

G. F. Herbert SMith

\section{Prof. Paul Reiss}

PAUL ReIss, professeur agrégé in the Faculty of Medicine at Strasbourg, was killed at St. Just (Cantal) on June 22, 1944, when helping to evacuate wounded members of the Maquis. He was forty. three years old. Reiss was born at Strasbourg. $\mathrm{He}$ was both personally attractive and one of the more brilliant of the younger French biologists. He was a pupil of Fred Vlès. His early work was on the relation of $p \mathrm{H}$ and $r \mathrm{H}$ to the physico-chemical equilibria in cells, from which he went on to enzyme studies, and thence to cancer work. He is buried in the crypt of the Sorbonne with others who fell in the Resistance Movement.

H. Munro Fox

WE regret to announce the following deaths :

Dr. Leopold Portheim, formerly director of the Biological Research Institute of the Academy of Science in Vienna, on May 21 , in London.

Prof. W. Rogowski, professor of electrotechnics at the Technical Highschool, Aachen, well known before the War for his electrotechnical work.

\section{NEWS and VIEWS}

\section{Research in Mechanical Engineering}

THE Government, through the Department of Scientific and Industrial Research, is setting up a special organisation to carry out scientific research in mechanical engineering to meet and, still more, to anticipate, the needs of industry and Government departments. The eventual annual expenditure will be in the region of $£ 250,000-£ 350,000$, although it is unlikely that this figure can be reached for some years because of the present difficulties in obtaining suitably qualified staff and buildings. The activities of the new body are intended mainly to supplement the research carried on in other research organisations in Great Britain, and will largely be confined to those fundamental problems which underlie all mechanical engineering. Thus the subjects in which research is expected to be carried out are: $(a)$ properties and strength of materials ; $(b)$ mechanics of solids, stress, stability and vibration of structures; (c) mechanics of fluids ; aerodynamics, gas dynamics and hydraulics in their mechanical engineering applications; $(d)$ lubrication, wear and mechanical engineering aspects of corrosion; $(e)$ mechanisms, engineering metrology, and noise control; $(f)$ mechanics of formation of materials; machine shaping of materials; $(g)$ heat transfer, heat exchange apparatus and applied thermodynamics. The location of the research station has not yet been decided. For the time being much of the work will be carried out at the National Physical Laboratory, while other work will be arranged for at universities and other institutions. It is clear that the new station will have to work in the closest liaison with the N.P.L., which has a long tradition, in its Engineering Division, of engineering research of high quality, and which will provide the nucleus, in due course, of the new organisation. Unfortunately no land is available close at hand for the building of the new station, which will require a considerable area.

Dr. G. A. Hankins, superintendent of the Engineering Division of the National Physical Laboratory, has been appointed director of mechanical engineering research. As with all other research organisations in the Department of Scientific and Industrial Research, the director will be advised by a board, the members of which will serve in their personal capacity and not as representatives of any organisation to which they may belong. The composition of the Mechanical Engineering Research Board is as follows : Dr. H. L. Guy (chairman); Mr. L. Akehurst, operative, London Passenger Transport Board; Prof. R. N. Arnold, professor of engineering, University of 